УДК 633.11(477.61), DOI 10.31210/visnyk2018.04.01

(C) 2018

Маслійов С. В., доктор сільськогосподарських наук,

Беседа О. О., кандидат технічних наук,

Дрель В. Ф., кандидат біологічних наук,

Арсієнко В. О., махістрант

Луганський національний університет імені Тараса Шевченка

\title{
ДОСЛІДЖЕННЯ ІНТЕНСИВНІЙОЇ ТЕХНОЛОГІЇ ВИРОЩУВАННЯ ОЗИМОЇ ПШЕНИЦІ ТА РІЗНИХ АГРОТЕХНІЧНИХ ПРИЙОМІВ У ЛУГАНСЬКІЙ ОБЛАСТІ
}

\author{
Рецензент - доктор сільськогосподарських наук А. М. Шевченко
}

Важко сьогодні уявити технологію вирощування зернових культур без використання регуляторів росту. I ие зрозуміло. Адже, ведучи мову про рентабельне виробництво зерна, ми неодмінно асоиіюємо ие з підвищенням рівня врожайності, яке неможливе без зростання індивідуальної продуктивності рослин.

Застосування ичих препаратів у поєднанні зі збільшенням культури землеробства та збільшенням масштабів застосування добрив сприяло значному росту урожайності озимої пшениці не тільки в дослідах, але й на виробничих масивах. Однак аналіз рівня урожаїв, які були отримані в Луганській області в наступні роки, показав, щзо величина його не завжди гарантується. Особливо різке падіння урожаӥв в окремі роки здавалось незрозумілим та неприйнятним після запровадження у виробництво прийомів, заснованих на застосуванні регуляторів росту.

Аналіз причин різкого падіння урожаїв озимої пшениці в окремі роки показав, щуо воно зумовлено, перш за все, епіфітотіями - грибковими захворюваннями та уикодженням рослинними шкідниками. Особливо різке зниження урожаїв відбувається в роки, коли паралельно з'являються два або три з перелічених факторів.

Вчені дійшли висновку, щьо після впровадження у виробництво високоврожайних сортів, застосування ретардантів росту потрібно проводити й боротьбу з хворобами та шкідниками на посівах озимої пшеницุi. Адже тільки на посівах, захищених від изих факторів, є можливість отримати високопродуктивні урожаї.

Ключові слова: озима пшениця, регулятор росту, обробіток, технологія вирощування, урожайність, агротехнічні прийоми, інтенсивна технологія.

Постановка проблеми. Важко сьогодні уявити технологію вирощування зернових культур без використання регуляторів росту. I це зрозуміло. Адже, ведучи мову про рентабельне виробництво зерна, ми неодмінно асоціюємо це 3 підвищенням рівня врожайності, яке неможливе без зростання індивідуальної продуктивності рослин.
У результаті ми отримуємо важкий, виповнений колос на тонкій, видовженій через використання значної кількості мінеральних добрив соломині. Це й $є$ ключовою причиною вилягання хлібів, недобору врожаю і погіршення його якості. У полеглих посівах погіршується забезпечення рослин елементами живлення та вологою, знижується продуктивність фотосинтезу, зростає ураження рослин хворобами, порушується процес закладки та наливу зерна. Значно ускладнюється й збирання полеглих посівів: знижується продуктивність комбайнів, подовжуються строки збирання, зростають втрати зерна, які можуть становити 25-30 \% і більше. Саме за таких умов господарювання використання регуляторів росту 3 ретардантною дією стає невід'ємним елементом технології вирощування зернових культур. Щоб чітко розуміти про що йдеться, як правильно та чи потрібно використовувати цей агрозахід, необхідно відповісти на низку питань .

Аналіз останніх досліджень і публікацій, у яких започтаковано розв'язання проблеми. В одному з оглядів цієї проблеми відомі вчені [5] вказували, що в дощові роки полягання зернових культур має катастрофічний характер, викликаючи колосальні збитки урожаю та різке погіршення його якість.

Роботи в цьому плані були широко розгорнуті Всесоюзним селекційно-генетичним інститутом, Краснодарским НДІСГ ім. П. П. Лук'яненка, ДУ Інституті зернових культур НААН України, Інститутом рослинництва ім. В. Я. Юр'єва НААНУ та іншими селекційними установами.

Вже у вісімдесяті роки з'явились солідні повідомлення щодо досліджень, де агротехнічні прийоми, розроблені на базі досліджень регуляторів росту, отримали широке узагальнення (книги: «Регуляторы роста растений» под редакцией академика ВАСХНИЛ Г. С. Муромцева [6], «Ретарданты - регуляторы роста растений» В. П. Деевой [2], «Повышение устойчивости зерновых культур к полеганию» А. К. Шиповского [7], 


\section{СІЛЬСЬКЕ ГОСПОДАРСТВО. РОСЛИННИЦТВО}

«Застосування регуляторів росту в сільському господарстві» Ф. Л. Калініна) [4].

Мета досліджень - дослідити різні агротехнологічні прийоми вирощування озимої пшениці в інтенсивній технології 3 використанням регуляторів росту та вплив на урожайність під час осіннього догляду за рослинами.

Завдання досліджень - визначити широкий спектр впливу препаратів: на проростання насіння озимої пшениці, пригнічення патогенів, росткові процеси, глибину залягання вузла кущення, перезимівлю посівів, формування продуктивності рослини та урожай.

Матеріали і методи дослідження. Дослідна робота проводиться 32016 року кафедрами технології виробництва і професійної освіти й біології та агрономії Луганського національного університету імені Тараса Шевченка на землях Навчально-наукової станції ЛНУ імені Тараса Шевченка й на полях фермерського господарства «Венера-2005» Старобільського району Луганської області, розташованого в північноцентральній помірно посушливій підзоні Степової північної зони.

Грунти дослідних ділянок - чорноземи звичайні на лісових породах із товщиною гумусового шару 65-80 см. Вміст гумусу в орному шарі грунту (за Тюріним) - 3,8-4,2 \%, валового азоту - 0,21-0,26\%, легкогідролізованого азоту (за Корнфілдом) - 105-150 мг/кг грунту, рухомого фосфору - 84-115 мг/кг і обмінного калію (за Чиріковим) - 81-120 мг/кг грунту. Реакція грунтового розчину була нейтральною або слаболужною. Об'ємна маса шару грунту 0-30 см -

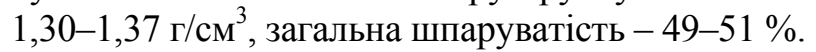

За рівнем агрокліматичних факторів територію проведення польових дослідів відносять до північного теплого і посушливого агрокліматичного району, головною особливістю якого $є$ різка континентальність 3 чітко вираженою сезонною контрастністю показників погодно-кліматичних елементів.

Попередник - чорний пар. Під час сівби вносили 60 кг/га аміачної селітри. Обробка пару виконувалась відповідно до загальних вимог для степової зони України. Під передпосівну культивацію вносили фосфорно-калійні добрива в дозі 60 кг/га.

У дослідах висівали районовані високопродуктивні сорта озимої пшениці, які різнилися за біологічними особливостями - середньорослі Чигиринка, Благодарка одеська та Антара.

У дослідах передбачалося проведення досліджень за трьома блоками: 1 - допосівна обробка насіння; 2 - обприскування посівів восени; 3 обробка посівів у разі поєднання двох або трьох перерахованих прийомів. Вказані варіанти розміщувалися в одному масиві в 3-4-кратній повторності. Це дозволило дати оцінку як в межах окремих блоків, так й по досліду в цілому. Математична обробка проводилась по всім варіантам досліду, що дає можливість аналізувати ступінь впливу як за кожним фактором окремо, так й оцінювати їх комплексну взаємодію.

Проведення дослідів та обробка отриманих результатів проводилися згідно 3 методикою польового досліду Доспєхова [3].

Результати досліджень. Вивчення досвіду розроблення та впровадження інтенсивних технологій вирощування озимої пшениці в світовій науці та практиці показують, що якщо боротьба 3 хворобами (в першу чергу, шляхом протруювання насіння) весь час вдосконалюється, особливо шляхом впровадження нових препаратів, то боротьба зі шкідниками, особливо в осінній період, у більшості випадків виконується звичайними агротехнічними заходами - перш за все, правильним чергуванням культур у сівозміні. При цьому до останнього часу боротьба зі шкідниками (злакові мухи, цикадки, тлі) практично не проводилась й вони залишались поза зором дослідників. Тільки в семидесяті роки в спеціальній літературі з'явився ряд робіт, в яких розглядались питання боротьби зі шкідниками в осінній період із використанням прийомів обробки посівів системними отрутохімікатами або допосівної обробки насіння цими препаратами. У той же час пошкодження цією групою шкідників посівів в окремі роки та зв'язані з цим розповсюдженням вірусні хвороби досягають значних розмірів.

Протягом осінньої вегетації, в залежності від особливостей року, сходи та стебла молодих рослин озимої пшениці можуть пошкоджувати шведська та гессенська мухи, зеленоглазка, стеблові блошки, смугаста хлібна блошка, шкідлива черепашка [1], більшу шкоду урожаю наносять вірусні та вірусоподібні хвороби, шкідливість яких може визивати масові епіфітотії. В більшості випадків переносниками та резерваторами інфекції цих хвороб є шкідники сільськогосподарських культур (тлі, цикади, кліщі та інші).

Так, вірус руської мозаїки розповсюджується полосатою (Prammotettix striatus L.) та шестикрапковою (Macrosteles laevis Rid.) цикадами. Зберігається патоген у зимуючих рослинах.

Тому, плануючи попередити ураження молодих рослин озимої пшениці можливими шкідниками, а також виключити перенос ними вірусних та вірусоподібних інфекцій на наступних етапах 


\section{СІЛЬСЬКЕ ГОСПОДАРСТВО. РОСЛИННИЦТВО}

органогенезу, розробляємо інтенсивну технологію вирощування цієї культури й включаємо обробку посівів системними ядохімікатами - «Рогор-С», «Бенорад».

Обробку посівів «Рогор-С» й його дотичними (БІ-58 БАСФ, фосфамід) та «Бенорадом» (вофатокс, паратіон-метил, фомідол) передбачалось проводити в два строки: в фазі 2-3-го листка та на початку кущення рослин дозою 0,5 кг/га. Передбачалось також співвідношення цих обробітків 3 протруюванням насіння «Байтан універсалом» та оприскуванням посівів проти хвороб «Байзафоном» у фазі виходу рослини в трубку.

Виходячи з отриманих даних, можна констатувати, що така обробка є особливо ефективною на фоні передпосівної обробки насіння «Байтан універсалом». На фоні окремого застосування «Байтан універсала» та спільно 3 ним «Рогор-С» збільшувалась кількість пагонів, листків, вторинних коренів та збільшувалась загальна суха маса рослин у порівнянні 3 контролем на 22,7 \%, а в порівнянні 3 обробкою насіння тільки «Байтан універсалом» - на
8,6 \% (табл. 1).

Протягом досліджень до початку поновлення весняної вегетації на досліджуваних варіантах досліду спостерігали різний стан рослин озимої пшениці після перезимівлі. Їх стан визначався головним чином характером прийомів передпосівного та осіннього догляду. Потрібно відмітити, що візуально виділялись рослини 3 ділянок, де «Байтан універсал» застосовувався як для передпосівної обробки насіння, так й одночасно 3 «Рогор-С» у фазі виникнення 2-3-го листка.

Виявлено, що до початку поновлення весняної вегетації ці рослини зберегли найбільшу кількість пагонів, листків, вторинних коренів, мали найбільшу масу сухої речовини (табл. 2).

Так, за 2017 р. біометричні заміри та підрахунки, проведені в пробах, відібраних на 10-й день після поновлення весняної вегетації, показали, що під час розрахунків на 100 рослин 3 насіння, обробленого «Байтан універсалом», кількість пагонів, листків, вторинних коренів було більше, відповідно, на 78, 136 та 97 у порівнянні з контролем.

\section{1. Вплив обробки посівів «Рогор-С» на ростові показники озимої пшениці до часу зупинки осінньӧ вегетації (сорт Благодарка одеська, за 2017 р.)}

\begin{tabular}{|c|c|c|c|}
\hline \multirow[b]{2}{*}{ Кількість на 100 рослин } & \multirow[b]{2}{*}{ Контроль } & \multicolumn{2}{|r|}{ Оброботка } \\
\hline & & $\begin{array}{c}\text { насіння «Байтан } \\
\text { універсалом» }\end{array}$ & $\begin{array}{c}\text { насіння «Байтан універсалом»+ } \\
\text { обприскування рослин «Рогор-С» } \\
\text { у фазі 2-3-го листка }\end{array}$ \\
\hline a) пагонів & 312 & 397 & 426 \\
\hline б) листків & 1130 & 1308 & 1498 \\
\hline в) вторинних коренів & 336 & 405 & 437 \\
\hline Загальна суха маса рослин (г) & 38,7 & 43,7 & 47,5 \\
\hline
\end{tabular}

\section{2. Біометричні показники рослин озимої пшениці в залежності від прийомів до початку поновлення весняної вегетації (сорт Благодарка одеська, за 2017 р.)}

\begin{tabular}{|c|c|c|c|}
\hline \multirow[b]{2}{*}{$\begin{array}{c}\text { Середній показник на } \\
100 \text { рослин }\end{array}$} & \multirow[b]{2}{*}{ Контроль } & \multicolumn{2}{|c|}{ Прийоми обробітку } \\
\hline & & $\begin{array}{c}\text { насіння } \\
\text { «Байтан універсалом» }\end{array}$ & $\begin{array}{c}\text { насіння } \\
\text { «Байтан універсалом»+ } \\
\text { обприскування рослин } \\
\text { «Рогор-С» }\end{array}$ \\
\hline 1 & 2 & 3 & 4 \\
\hline Висота, см & 16 & 17,2 & 17,9 \\
\hline $\begin{array}{l}\text { Кількість: } \\
\text { а) пагонів }\end{array}$ & 306 & 384 & 415 \\
\hline б) листків & 1063 & 1199 & 1407 \\
\hline в) вузлових коренів & 318 & 415 & 448 \\
\hline $\begin{array}{l}\text { Маса сухої речовини, г; } \\
\text { а) надгрунтової частини }\end{array}$ & 27,7 & 31,2 & 33,1 \\
\hline б) підгрунтової частини & 9,5 & 11,3 & 12,7 \\
\hline в) усього рослин & 37,2 & 42,5 & 45,8 \\
\hline
\end{tabular}


При цьому їх загальна суха маса перевищувала контроль на $14,2 \%$. У варіанті, де рослини виросли $з$ насіння, обробленого «Байтан універсалом», у фазі утворення 2-3-го листка були додатково обприскані «Рогор-С», кількість пагонів, листків, вторинних коренів збільшилось, відповідно, на 8,0-17,3\%, а загальна суха маса - на $7,8 \%$.

Результати дослідів, де вивчалась доцільність застосування «Рогор-С» та «Бенораду» 3 першого року їх проведення, привернули нашу увагу дуже високою ефективністю. Наприклад, у варіанті, де обприскування посівів цими препаратами було проведено в фазі 2-3-го листка, приріст урожаю на низькорослому сорті Антара склав у 2017 році 4,0 ц/га, Чигиринка - 5,9-6,9 ц/га, а Благодарка одеська дав 10,3 ц/га. Дещо вище (6,9-10,7 ц/га) - приріст урожаю, отриманий у варіантах, де на посівах, оброблених «Рогор-С» у фазі 2-3-го листа, обробку повторювали в фазі кущення «Бенорадом».

Висновки. В роки проведення дослідів (2017-2018 рр.) приріст урожаїв під впливом досліджуваних препаратів був достатньо високим та коливався за сортами в середньому від 3,5 до 7,5 ц/га. Значно нижча прибавка врожаю була отримана на низькорослому сорті Антара. На середньорослих сортах Чигиринка та Благодарка одеська в усі роки вони були більші. Необхідно відмітити, що значно більш стійкі та більші прибавки спостерігались у сорту Благодарка одеська.

У співвідношенні ефективності препаративних форм отрутохімікатів («Рогор-С» та «Бенора») потрібно відмітити більш стабільну захисну дію «Рогор-С». Під впливом вказаних препаратів по сорту Чигиринка середня прибавка урожаю

\section{БІБЛІОГРАФІЯ}

1. Брянщев Б. О. Сільськогосподарська ентомологія. - К. : Урожай, 1968. - 360 с.

2. Деева В. П. Ретарданты - регуляторы роста растений - М. : Наука и техника, 1980. - 176 с.

3. Доспехов Б. А. Методика полевого опыта (с основами статистической обработки результатов исследований) / Б. А. Доспехов. - М. : Агропромиздат, $1985 .-351 \mathrm{c.}$

4. Калінін Ф.Л. Застосування регуляторів росту в сільському господарстві. - К. : Урожай, 1898. - 165 с. склала, відповідно, 5,5 та 4,4 ц/га, по сорту Благодарка одеська - 6,4 та 5,1 ц/га, а по сорту Антара вони однакові - 3,5 ц/га.

У варіантах, де обробку рослин проводили в два строки («Рогор-С» у фазі 2-3 листків, а «Бенорад» - у фазі кущення), достовірного збільшення урожаю не отримали. Вочевидь, що для захисту посівів від вказаних шкідників достатньо однієї обробки, тому коливання урожаїв й знаходились в межах помилки дослідів.

У варіантах, де вивчали поєднану дію «Рогор-С» під час обробки рослин в фазі 23 листків восени та додатково обприскували їх «Байзафоном» у фазі виходу в трубку, також не було отримано стійкого приросту урожаю. Але на сорті Благодарка одеська спостерігалася тенденція до збільшення.

Напевно, рослини зі здоровою (неушкодженою сисними шкідниками) листовою поверхнею проявляють вищу стійкість до ураження борошнистою росою. Під час проведення спеціальних підрахунків у дослідах така закономірність чітко проявляється, особливо у варіанті, де рослини 3 осені оброблялись два рази - в фазі 2-3 листків «Рогор-С» та в фазі кущення «Бенорадом», а навесні - в фазі виходу в трубку - «Байзафоном». У цьому варіанті приріст урожаю в розрізі сортів в роки проведення дослідів був найвищим та найстійкішим. У середньорослих сортів (Чигиринка та Благодарка одеська) за роки досліджень прибавки врожаю менше 5,0 ц/га не отримували, в більшості випадків вони знаходились в межах 6-7 ц/га, а в окремі роки досягали 11,1 ц/га. У короткостибельного сорту Антара в цьому варіанті досліду в роки вивчення прибавки урожаю коливались від 2,5 до 10,5 ц/га.

5. Петинов Н. С., Прусакова Л. Д. // Вестник AH CCC. - 1965. - №6. - С. 19-22.

6. Прусакова Л. Д., Чкаников Д. И., Муромиев Г. С. Применение регуляторов роста в растениеводстве // Регуляторы роста растений. - М. : Колос, 1979. - С. 174-180.

7. Шиповский А. К., Щутов Г. К. Влияние хлорхолинхлорида на устойчивость к полеганию и на урожай зерновых культур в условиях Белоруссии // Химия в сельском хозяйстве. - 1969. №1. - C. 51-53. 


\section{ANNOTATION}

Masliiov S. V., Beseda A. A., Drel V.F., Arsiienko V. O. Research of intensive technology of winter wheat plants and various agricultural approaches in Luhansk region.

Nowadays it is difficult to imagine the technology of cultivating grain crops without the use of grow regulators. And this is understandable. After all, speaking about the cost-effective production of grain, we necessarily associate this with an increase in the level of yield, which is impossible without the growth of individual productivity of plants.

The use of these drugs in conjunction with the increase in the culture of agriculture and the increase in the use of fertilizers contributed to a significant increase in winter wheat yields not only in experiments, but also in production massifs. However, analysis of the level of yields that was obtained in Luhansk region in next years has shown that its size is not always guaranteed. Especially sharp drop in yields in some years seemed incomprehensible and unacceptable after introducing into the production of techniques based on the use of growth regulators.

Analysis of the causes of a sharp drop in winter wheat yields in some years has shown that it is due primarily to the manifestation of epiphytotic diseases - fungal diseases and damage to plant pests. Especially sharp decrease of crops occurs in years when two or almost three of the listed factors appear simultaneously.

Scientists came to the conclusion that after introduction of the application of growth retardants into production of high-yielding varieties, it is necessary to carry out the fight against diseases and pests on winter wheat crops. After all, only crops protected from these factors have the opportunity to obtain high yield crops.

Key words: winter wheat, grow regulator, cultivation, technology of cultivation, yield, agrotechnical receptions, intensive technology. 